\title{
Development of Mangrove Ecotourism in Bandar Bakau Dumai Based on Disaster Mitigation
}

\author{
Aras Mulyadi*, Efriyeldi, Rasoel Hamidy, Nofrizal \\ Department of Environmental Science, Graduate Program, University of Riau, Pekanbaru 28131, Indonesia
}

Corresponding Author Email: aras.mulyadi@lecturer.unri.ac.id

https://doi.org/10.18280/ijsdp.160716

Received: 12 September 2021

Accepted: 17 November 2021

\section{Keywords: \\ Bandar Bakau Dumai, mangrove eco- tourism, disaster mitigation}

\begin{abstract}
Natural disasters that occur in the city of Dumai such as degradation of mangrove forests, coastal abrasion and tidal flooding can be mitigated by maintaining the existence of mangrove forests. Mangrove forests have important benefits on the coast of the city of Dumai, so they need to be protected together. One of the efforts to maintain the existence of mangroves can be through the use of mitigation-based mangrove ecotourism, especially in the Bandar Bakau area of Dumai City. The data collection technique in this study used a quadratic transect and added secondary data from the relevant agencies. Based on the results of the study found 9 types of mangroves that have a role as mitigation in ecotourism locations and there are biota supporting tourism, namely 13 species of birds, 7 species of reptiles and 16 species of molluscs. To maintain the sustainability of the ecotourism area of Bandar Bakau, several disaster mitigations have been carried out for retaining cliffs (revetment), reforestation of mangroves, construction of facilities that adapt to the environment, coastal education, and outreach to the community. In addition, it is very potential to develop several other forms of mitigation such as: beach nourishment, breakwater or construction of embankments to minimize abrasion, as well as construction of diversion canals and tidal flood control gates, strengthening regulations. legislation, making land use policies, policies on flood and wave resistant building standards, policies on exploration and community economic activities, promoting local cultural wisdom of maritime communities.
\end{abstract}

\section{INTRODUCTION}

The coastal zone is a transitional area between land and sea. As a transitional area, this region is undergoing very dynamic changes. These changes are caused by fluctuating environmental factors, such as temperature, salinity, currents, tides, and waves. The fluctuating environmental factors cause problems for coastal areas [1]. states that disasters occur in coastal areas like tsunamis, floods, erosion and abrasion, and sea-level rise. Dumai is a coastal city that also faces several environmental problems. Issues of coastal environmental problems in Dumai City include mangrove forest degradation, coastal abrasion, and tidal flooding. In three years, the mangrove area has been reduced from 50 ha in 2017 to 20 ha in 2019 [2]. Coastal abrasion is a natural phenomenon that has been seen to threaten the coast. Tidal flooding in Dumai City is becoming more and more common; this happens because of the sloping topography of the Dumai coast plus the possibility of sea-level rise. The four sub-districts in Dumai City that were submerged by tidal waves in October 2020 were Dumai City, West Dumai, South Dumai, and Sungai Sembilan, with water levels reaching 20 to 40 centimeters [3].

One of the strategies that can be used for disaster mitigation is to utilize mangrove plants. Magrove plants have important benefits in coastal areas. One of the functions of mangrove forests is to prevent potential disasters in coastal areas [4], can be used as disaster mitigation (wave absorbers, beach protectors, breakwaters and tsunamis) [5], green belts [6], as well as coastal protection, fisheries, hydrology, and carbon sinks [7].

The existence of mangrove forests required to be optimized because one of the functions of mangrove forests can prevent potential disasters in coastal areas [4], it can be used as disaster mitigation (wave absorbers, beach protectors, breakwaters, and tsunamis) [5], green belt [6], and coastal protection, fisheries, hydrology, and carbon sinks [7]. Efforts to maintain, conserve, and revitalize mangrove ecosystem functions can be realized through an eco-tourism approach to governance [810]. Eco-tourism is a tourism activity that has a responsibility to nature, society, and the environment. The concept of ecotourism development is according to environmental and cultural conservation and provides economic benefits to the community. According to literature [11], the basis for tourism development is more robust according to social, economic, environmental ecology, and community culture. Besides having a role as protection for the preservation of biological diversity, the development of eco-tourism, and the prevention of theft of biological diversity (biopiracy), it is also a supporter of regional economic growth and a function of defending the sovereignty of the Republic of Indonesia. Research by Mulyadi et al. [12] revealed that in order to make Bandar Bakau mangrove eco-tourism competitive and sustainable, it is necessary to apply the concept of conservation-based development and disaster mitigation. On that basis, this study aims to analyze the development of mangrove eco-tourism in Bandar Bakau Dumai based on conservation and disaster 
mitigation. The hope is that the development of Bandar Bakau mangrove eco-tourism can be used as an icon of Dumai city natural tourism.

\section{RESEARCH METHODS}

\subsection{Data collection and analysis}

Collecting data on mangroves and ecotourism supporting organisms was carried out using a exploration method using quadratic transects at 4 research stations. Identification of mangroves using the book of mangrove identification from Noor et al. [13]. The data collected in the form of eco-tourism potential, disaster potential, and other forms of disaster mitigation developed at the Bandar Bakau Dumai mangrove eco-tourism site. The products and status of eco-tourism activities, potential disasters, and forms of mitigation were identified through direct field observations and interviews with Bandar Bakau managers. Secondary data were obtained from the Dumai City government and related literature. Then the data were analyzed descriptively using the theoretical basis and the results of previous research [14].

\subsection{Location of study}

The research was conducted from June to November 2020 in the Mangrove Ecotourism Area of Bandar Bakau, Dumai City, Riau. Dumai city, located on the east coast of Sumatra, is the busiest port city in Riau Province. Dumai has unique beach characteristics with brownish-yellow sand, also has a mangrove ecosystem with a diversity of biota as an attraction for tourists. Literature [15] shows that the direction of tourism development in Dumai City favors natural, historical, religious, sports, culinary, and shopping tourism. Literature [16] has exposed at least 14 exciting tourist attractions in Dumai City (Figure 1).

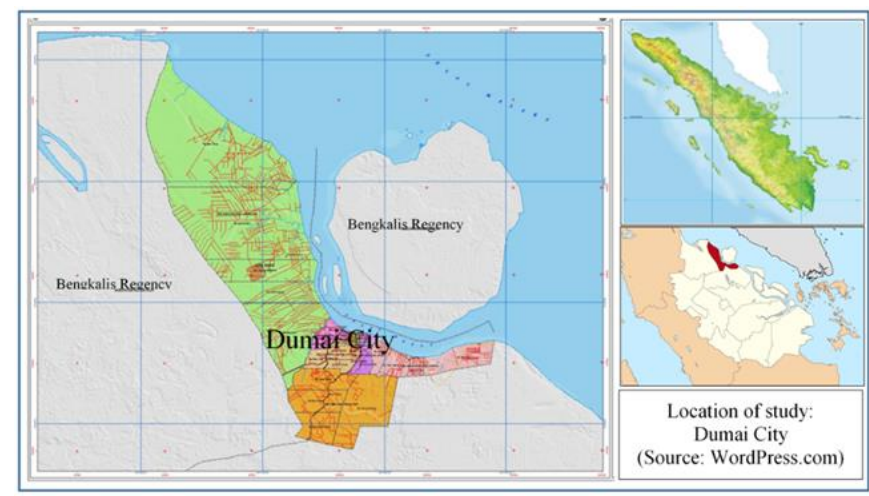

Figure 1. Dumai city map, Riau

Among the tourist attractions that take advantage of natural conditions is mangrove eco-tourism in Bandar Bakau Dumai (Figure 2). Data and research on Mangrove Ecotourism in Bandar Bakau Dumai with various development problems are still minimal. Bandar Bakau Dumai has been the location of research by several researchers [17-24].

The Bandar Bakau Dumai mangrove eco-tourism site is managed by the Non-Governmental Organization for Marine Nature Lovers (NGO-PAB). This area is located on Jalan Nelayan Ujung, Pangkalan Sesai Village, West Dumai District, Dumai City, Riau Province. Geographically, Pangkalan Sesai village is bordered to the north by the Rupat strait, to the south by Tetap Simpang Darul Ikhsan village, to the east by Laksamana village, and to the west by Purnama village. The population of Pangkalan Sesai village is 9,265 people, consisting of 4,701 males and 4,564 females. The population comprises ethnic Malays, Javanese, and Minangs as 4,980 people, 1,853 people, and 1,472 people, followed by Nias as 275 , Kubu as 257, Batak as 220, Aceh as 112, and others 48.

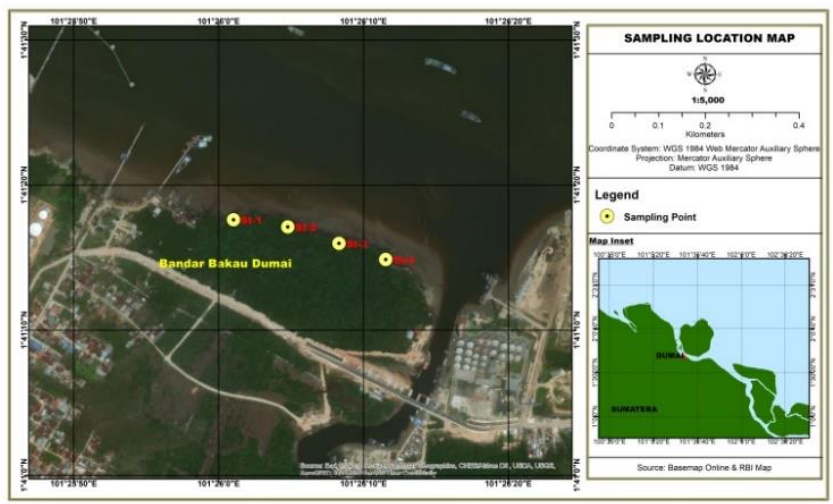

Figure 2. Map of Bandar Bakau Dumai mangrove sampling location

\section{RESULT AND DISCUSSION}

\subsection{Mangrove ecotourism attractions and products in Bandar Bakau Dumai}

Mangrove eco-tourism attraction in Bandar Bakau Dumai is supported by the diversity of mangrove vegetation and fauna associated with mangroves. Research at this eco-tourism site in Bandar Bakau identified 17 mangrove species spread to nine families. Most of the mangrove species were composed of the Rhizopraceae family (6 species), then the Combretaceae, Sonneratiaceae, and Verbenaceae (2 species each), and the Arecaceae, Pteridaceae, Malvaceae, Meliaceae, and Rubiaceae families (1 species each) (Table 1). Mulyadi and Amin [19] identified four valid mangrove species more dominant in Bandar Bakau Dumai, namely A. alba, $R$. apiculata, S. alba, and X. granatum.

The previous study explains that the mangrove species $\mathrm{X}$. granatum has the highest density, Basal Area (BA), and Important Value (NP) compared to other mangrove species with a value of 2,600 trees/ha (density), 1,402 $\mathrm{m}^{2} / \mathrm{ha}$ (BA), as well as 163.70 (NP). On the other hand, although R. apiculata has a density value (500 trees/ha), BA $\left(838.94 \mathrm{~m}^{2} / \mathrm{ha}\right)$, and NP (76.54) below the density value of $X$. granatum, R. apiculata is a mangrove with trees highest (mean height $8.93 \mathrm{~m}$ ) in Bandar Bakau.

The diversity of existing mangrove vegetation is a living habitat for the fauna of the mangrove ecosystem. Several faunas that live in association with mangroves in the Bandar Bakau Dumai mangrove forest include groups of birds, reptiles, mammals, insects, fish, mollusks, and crustaceans. Various species of birds were identified in Bandar Bakau: Susanto et al. [20] found as many as eight species of birds in the mangrove forest area of Bandar Bakau Dumai, and Asbullah et al. [17] found seven species (Table 2).

Other species, several other faunas inhabit the mangrove forest tourism area, including reptiles, mammals, and insects $[17,20]$ (Table 3$)$. 
Fish, mollusks, and crustaceans also inhabit the Bandar Bakau mangrove forest area. Fish use the mangrove ecosystem as a permanent habitat, spawning ground, feeding ground, and nursery ground. Species of fish include shoot fish (Periophthalmus $s p$ ) which is the dominant species was found, catfish (Plotosus $s p$ ), chopper (Toxotes $s p$ ), pufferfish (Tetraodon $s p$ ), mullet (Mugil sp) [17]. Mollusks of the gastropod and bivalve species are pretty numerous in this area. [25] found 12 families of gastropods in Bandar Bakau, while bivalve species were also found in this area [26] (Table 4). Crustaceans are a group of fauna that live on the surface and in mangrove forest areas. Species of crustaceans found on the surface of Bandar Bakau Dumai include crab species: Scylla tranquebarica, Scylla olivacea, Penaeus sp, Uca sp. and hermit crabs (Thalassina anomala) that live burrowing at the bottom of the mangrove forest.

Besides the wealth of fauna and flora, Banar Bakau Dumai also has an eco-tourism attraction in beautiful nature, sea panoramas, and the typical culinary of Bandar Bakau. The favorites food includes sour, spicy catfish, fried tuna, and "sambal belacan" and sago plates, available Soto, meatballs, grilled meatballs, fried cassava, fried bananas some fast food. The type of drink that becomes an idol in this place is young coconut, both served whole in a coconut shell and already mixed with ice as a cooler. Sitting in the yard or harbor jetty, in the tavern "warung," and the lodges while tasting a variety of culinary delights, although still traditional and outskirt, accompanied by a gust of wind and sea views are the main attraction for visitors to Bandar Bakau.

In addition, Bandar Bakau Dumai has also begun to develop hand-drawn batik with mangrove motifs. This mangrove batik motif aims to campaign and instill a sense of love for the mangrove ecosystem. Not only that, various mottos and beautiful words about saving mangroves, the introduction of Bandar Bakau, and Dumai City have also been pinned on Tshirts produced by Bandar Bakau. These two fashion products, batik, and T-shirts, are memorable souvenirs that tourists can take after visiting Bandar Bakau Dumai.

Table 1. Species of mangroves found in the eco-tourism area of Bandar Bakau

\begin{tabular}{|c|c|c|c|c|}
\hline No. & Family & Scientific Name & Local Name & Characteristics \\
\hline 1. & Arecaceae & Nypa fruticans & Nipah & Erosion prevention \\
\hline 2. & Combretaceae & $\begin{array}{l}\text { Lumnitzera littorea } \\
\text { L. racemosa }\end{array}$ & $\begin{array}{c}\text { Teruntum, sesop merah } \\
\text { Susup, teruntum bunga putih }\end{array}$ & Erosion prevention \\
\hline 3. & Malvaceae & Heritiera littoralis & Dungun & Erosion prevention \\
\hline 4. & Meliaceae & Xylocarous granatum & Nyirih & Erosion prevention \\
\hline 5. & Pteridaceae & $\begin{array}{l}\text { Acrostrichum sp. } \\
\text { Bruguiera oymnorriza }\end{array}$ & $\begin{array}{c}\text { Piai } \\
\text { Tumu }\end{array}$ & Erosion prevention \\
\hline 6. & Rhizopraceae & $\begin{array}{l}\text { B. parviflora } \\
\text { Ceriops tagal } \\
\text { Rhizophora apiculata } \\
\text { R. mucronata } \\
\text { R. stylosa }\end{array}$ & $\begin{array}{c}\text { Lenggadai } \\
\text { Tengar } \\
\text { Bakau, bakau putih } \\
\text { Bakau, belukap, bakau kurap } \\
\text { Bakau, bakau merah }\end{array}$ & $\begin{array}{c}\text { Ultimate prevention of Abrasion and } \\
\text { breakwater }\end{array}$ \\
\hline 7. & Rubiaceae & Scyphiphora hydrophyllacea & Cingam & Erosion prevention \\
\hline 8. & Sonneratiaceae & $\begin{array}{l}\text { Sonneratia alba } \\
\quad \text { S. ovata }\end{array}$ & $\begin{array}{l}\text { Prepat } \\
\text { Kedabu }\end{array}$ & $\begin{array}{c}\text { Ultimate prevention of abrasion and } \\
\text { breakwater }\end{array}$ \\
\hline 9. & Verbaneceae & $\begin{array}{l}\text { Avicennia alba } \\
\text { A. marina }\end{array}$ & $\begin{array}{l}\text { Api-api putih } \\
\text { Api-api jambu }\end{array}$ & $\begin{array}{c}\text { Ultimate prevention of abrasion and } \\
\text { breakwater }\end{array}$ \\
\hline
\end{tabular}

Table 2. Types of birds found in Bandar Bakau Dumai

\begin{tabular}{cccc}
\hline No. & Local name & Scientific name & References \\
\hline 1. & Burung Perenjak & Printa famillaris & \\
2. & Burung Kacek & Copshychus saularis & \\
3. & Burung Kipas & Rhipidura javanica & \\
4. & Burung penghisap nectar & Leptocoma calcostetha & \\
5. & Burung elang & Hallastur indicus & \\
6. & Burung Elang & Ictinateus malayensis & Asbullah et al. [17] \\
7. & Burung Raja Udang Biru & Halcyon smyrnensis & Susanto et al. [20] \\
8. & Burung Raja Udang & Alcedo atthis & \\
9. & Burung Gagak & Corvus enca & \\
10. & Burung layang-layang & Collocalia esculenta & \\
11. & Bangau Putih & Ibis cinerius & \\
12. & Burung Merbah & Pycnotus sp & \\
13. & Burung Camar & Sterna albifrons & \\
\hline
\end{tabular}

Table 3. Species of reptiles, mammals, and insects are found in the mangrove forest area of Bandar Bakau Dumai

\begin{tabular}{cccccc}
\hline & Reptile & \multicolumn{2}{c}{ Mammals } & \multicolumn{2}{c}{ Insecta } \\
\hline Biawak & Varumus salvator & Musang & Cynogale sp.i & Laba-laba & Cyptophora sp. \\
Kadal & Emia atracostata & Berang-berang & Lutra lutra & Capung & Aeshinidae sp. \\
Ular air & Trimeresurus sp. & Kelelawar & Rhinolophus affinis & Lalat & Drossophila sp. \\
Ular bakau & Fondonia sp. & Lutung & Presbytis cristata & Lepah & Apis dorsata \\
Ular tiung & Boiga dendrophila & Monyet ekor panjang & Macaca fascicularis & Semut rangrang & Oecopphila sp. \\
Ular daun & Bangurus laticep & & & Kupu-kupu & Chilades sp. \\
Bengkarung & Mabouya sp. & & & Nyamuk & Culicidae sp. \\
\hline
\end{tabular}


Table 4. Species of mollusks found in Bandar Bakau Dumai

\begin{tabular}{cccc}
\hline \multicolumn{2}{c}{ Gastropoda } & \multicolumn{2}{c}{ Bivalva } \\
\hline Siput Mata Merah & Cerithidae obtusa & Kerang darah & Anadara granosa \\
Siput babi & Ellobium sp. & Kerang sunset & Gari elongate \\
Siput timba & Nerita lineate & Kerang hijau & Mytilopsis leucopiata \\
Siput hitam & & Kerang berusuk & Geukensia demissa \\
Siput blongan & Tiram & Ostrea sp. \\
Teritip & Bernacle sp. & Tiram bakau & Saccostrea cucullata \\
& Tiram gepeng & Ostrea edulis \\
& Tiram atlantik & Crassostrea gigas \\
& Tiram timur & C. virginica \\
& Tiram batu & C. iredalei \\
& Kerang pohon & Isognomon alatus \\
& Kerang ibau & Tellina palatum \\
& Kerang lokan & Polymesoda expansa \\
& Kerang & Lutraria lutraria \\
& Kerang kepah & Polymesoda erosa \\
& Kerang kerek & Gafrarium tumidum \\
\hline
\end{tabular}

Table 5. Product and status of mangrove eco-tourism activities in Bandar Bakau Dumai

\begin{tabular}{|c|c|c|}
\hline \multirow{2}{*}{ No } & \multirow{2}{*}{ Mangrove Ecotourism Products } & \multirow{2}{*}{\begin{tabular}{|c|} 
Activity Status \\
Well Managed/Not Well Managed
\end{tabular}} \\
\hline & & \\
\hline \multicolumn{3}{|c|}{ a. Mangrove Special Interest Ecotourism Products } \\
\hline 1. & $\begin{array}{c}\text { Enjoy the vegetation and mangrove atmosphere by tracking } \\
\text { mangrove }\end{array}$ & $\begin{array}{l}\text { Not well managed because there are still minimal } \\
\text { arrangements }\end{array}$ \\
\hline 2. & Photography/selfie & Not managed properly due to the lack of objects/photobooths \\
\hline 3. & Bandar Bakau Nature School (SABB) & Well managed \\
\hline 4. & Mangrove Research & Well managed \\
\hline 5. & Mangrove Planting & Well managed \\
\hline 6. & Mangrove Education and Tour & Not well managed due to lack of signs and vegetation names \\
\hline \multicolumn{3}{|c|}{ b. Mangrove Ecotourism Support Products } \\
\hline 7. & Enjoy the Panorama of Nature and the Sea & Well managed \\
\hline 8. & Seeing the Activities of Fishing Community and Shipyards & Not well managed due to minimal arrangement \\
\hline 9. & Culinary tours and souvenirs & Well managed \\
\hline 10. & Cultural Events & Well managed \\
\hline 11. & Jogging and Cycling & Not well managed due to minimal arrangement \\
\hline
\end{tabular}

In Bandar Bakau Dumai, eleven eco-tourism products have been developed, which are distributed to two product groups, such as mangrove particular interest eco-tourism products and mangrove eco-tourism supporting products (Table 5). Particular interest eco-tourism products in the Bandar Bakau Nature School (SABB), mangrove research, and planting have been well managed. Meanwhile, enjoying the mangrove vegetation and atmosphere through tracking, photography, selfie, and mangrove education and tours is still not well managed due to the lack of arrangement, objects, signs, and vegetation names. Mangrove eco-tourism supporting products in the form of activities to enjoy natural and sea panoramas, culinary tours and souvenirs, and cultural events have been well managed; except for activities to see the activities of fishermen and shipyards, jogging and cycling are still not appropriately managed due to the lack of arrangement.

\subsection{Potential disasters for mangrove ecotourism in Dumai Dumai}

The study results indicate that natural disasters that have the potential to occur in Dumai City are tidal flooding and coastal abrasion. Dumai City has a topography mainly composed of lowlands (0 - 25 masl) in the north, facing directly to the Rupat strait. The waters of the Rupat strait are semi-enclosed and have waves and currents controlled by the wind and tidal seasons, with mixed tidal types tending to double daily. At high tide, the water flows in from the Melaka strait; on the other hand, at low tide, the water flows from the coast of Dumai towards the Melaka Strait. At normal high tide, the wave height in the Rupat strait ranges from $0.07-0.21 \mathrm{~m} \mathrm{[27],}$ and at the full moon, it ranges from $0.12-0.90 \mathrm{~m}$ [28]. Current velocity recorded at the full moon in the Rupat strait ranges from $0.22-0.82 \mathrm{~m} / \mathrm{sec}[27,28]$. In these conditions, Dumai City is often a subscription to tidal floods, even with the regular frequency and the volume getting higher. It is thought to be a result of global warming, which triggers sea levels to rise due to a decrease in coastal topography. Tidal flooding has been recorded as threatening community safety and can even destroy various forms of buildings around the coast of Dumai, including the eco-tourism area of Bandar Bakau.

Abrasion is also a severe threat to the coastal area of Dumai city. Even though there is no exact data regarding the rate of abrasion in Dumai city, the manager of Bandar Bakau Dumai estimates that the biggest threat to the sustainability of mangroves is massive abrasion. If the Dumai government and the Provincial Government of Riau do not move quickly to deal with abrasion in Bandar Bakau, the abrasion is estimated to reach 25 meters within five to seven years. Of course, this is a severe threat to the existence of Bandar Mangroves in Dumai City [29].

The occurrence of abrasion caused by the waves of wave energy is a phenomenon that often occurs in coastal areas. The magnitude of the threat of abrasion in Dumai Mangrove Port mainly comes from oceanographic factors in the form of waves and tidal currents and is triggered by human factors in 
the form of land clearing for construction and cutting of vegetation on the coast.

\subsection{Disaster mitigation in mangrove ecotourism in Bandar Bakau Dumai}

For maintaining the sustainability of mangrove eco-tourism from the threat of natural disasters, it is necessary to carry out disaster mitigation efforts. Mitigation is an effort that is carried out preventively to minimize the negative impact of a natural disaster in the future. For coastal areas and small islands, natural disaster mitigation efforts can be carried out structurally and non-structurally [1]. On the other hand, he said that structural mitigation was carried out through technical efforts, both artificially and naturally. Coastal problems are caused mainly by human intervention; non-structural mitigation efforts are carried out by adjusting and regulating community activities in line with structural mitigation efforts. Prabowo and Buchori [30] suggest that non-structural forms of mitigation that have been initiated by the community in minimizing coastal abrasion in the Coastal area of Semarang city are the development of mangrove eco-tourism and education, human resource empowerment, and coastal area management.

This study has identified at least 5 (five) disaster mitigation activities that have been implemented in Bandar Bakau Dumai, namely: 1) construction of cliff protection (revetment), 2) mangrove restoration, 3 ) construction of eco-tourism facilities that adapt to the natural environment, 4) coastal education, and 5) counseling on the potential of eco-tourism as disaster prevention. The first three activities are more of structural mitigation, and the last two activities are non-structural mitigation. In line with the research [31] identified seven subelements of natural disaster mitigation in the Indramayu and Ciamis coasts, including the making of legislation and standard norms for manual procedures, socialization, selfrescue systems, assistance for standard building construction, early warning systems, combined mangrove restoration - coral reefs-beach revitalization, as well as a combination of breakwaters-abrasion absorbers-sedimentation-retaining moving parallel to the coast.

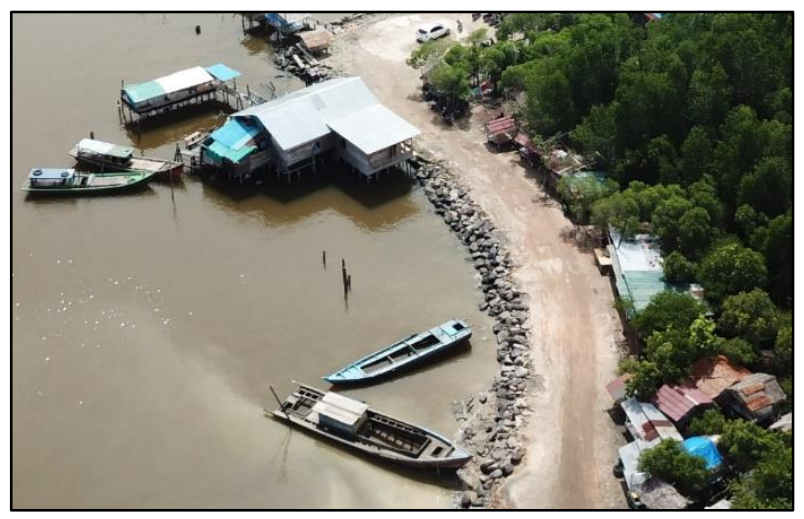

Figure 3. The revetment building with a dump stones system in Bandar Bakau Dumai (Source: Aras Mulyadi Personal Documentation Year 2020)

\subsubsection{Coastal cliff protection (Revetment)}

Kurniawan [32] stated that beach abrasion prevents, a coastal protection structure is required that functions break, reflect, and absorb wave energy. The coastal cliffs protection from the threat of abrasion, direct "cliff construction" or revetment can be done [33]. This revetment was built with the function of strengthening slopes or cliffs from current and wave scouring. The revetment built in Bandar Bakau Dumai acts as a barrier to the waves and tidal currents coming from the sea. Where the construction of the revetment in this place is in the form of piles of bulk stones (dump stones) arranged along the shoreline. The revetment built in Bandar Bakau Dumai acts as a barrier to the waves and tidal currents coming from the sea. Where the construction of the revetment in this place is in the form of piles of bulk stones (dump stones) arranged along the shoreline (Figure 3). The bulk stones are large stones arranged from the base to the cliff's height, which become one unit with the cliff so that the stability of the slope is the stability of the overall structure.

\subsubsection{Mangrove restoration}

The mangrove restoration is activities for planting mangroves along the coast where abrasion has occurred and in zones where the mangrove vegetation has been degraded. Mangrove vegetation has a diverse and robust root system. With such a structure, the function of mangroves is excellent as a protector of coastal areas from the threat of erosion and abrasion, protecting residential areas from storms and winds from the sea, preventing seawater intrusion, as a place to live and breed various wildlife. The use of mangrove forests for the protection of coastal areas from various coastal disasters has been studied by several experts, such as natural disaster mitigation [1, 31], tsunami mitigation [34], seawater intrusion mitigation [35], and global warming mitigation [7]. Furthermore, Indarsih and Masruri [36] found that coastal abrasion mitigation efforts in Rembang Regency were more effective based on natural ecosystems, such as maximizing the existence of mangrove vegetation through planting mangroves along the coast. Oni et al. [37] have also noted that mangrove ecosystems have potential benefits as conservation and disaster mitigation areas in coastal areas. The rehabilitated mangrove ecosystem in Karangsong at least protects the pond area from abrasion of approximately 100 ha.

Mangrove planting in Bandar Bakau Dumai has been going on since the beginning. Some of the seeds already exist in the Mangrove City, such as Avicennia sp, Bruguiera sp, Rhizophora sp, Sonneratia sp, and some are imported from other locations. In addition to instilling a caring value and a sense of responsibility towards the environment, this activity also enriches mangrove vegetation species and density. Asbullah et al. [17] noted that 53,648 mangroves had been planted in Bandar Bakau Dumai up to 2018. Various government agencies have carried out planting activities both from and outside the Dumai city, such as educational institutions (starting from Kindergarten to Higher Education), Riau Provincial Government, Dumai Regional Government, DPRD, Indonesian Forces (TNI), Indonesian Police Departement (POLRI), Non-Government Organization (NGOs), and the Companies and several people specific.

The pattern of developing a mangrove planting scheme carried out in Bandar Bakau Dumai is in the form of an independent pattern and a participatory pattern. An independent planting pattern is a form of planting and maintenance carried out independently by the manager of Bandar Bakau Dumai. A participatory planting pattern is a form of procurement of seeds, and the community or visitors carry out mangrove planting while the manager of Bandar Bakau carries out the maintenance. Participatory planting patterns are generally carried out in general planting methods 
and "pohon tokoh". The general planting method is carried out by planting mangrove trees in bulk by the community or visitors, which is carried out only once, then maintenance is carried out by the manager of Bandar Bakau. While planting "pohon tokoh", using a tree adoption pattern, where mangrove planting is carried out by community leaders, officials, or "public figures," then maintenance is carried out by the manager of Bandar Bakau using incentives provided by the figures in question. Several benefits can be taken from the "pohon tokoh" program in Bandar Bakau Dumai, including showing that the community or figures become actors in saving the environment through direct participation; instill a sense of responsibility towards environmental conservation; reduce the potential loss of mangrove diversity; maintain the ecological, biological and economic functions of the mangrove ecosystem; and controlling environmental disasters. It has been recorded that several figures who already have trees in Bandar Bakau include: the Minister of Tourism of Indonesia, several deputies at the Indonesian Ministry of Tourism, the Governor of Riau, Forkopimda Riau (Head of Riau Regional Police, Head of Riau Attorney General's Office, Military District Commander 031 WB, Chairman of Riau DPRD), Chairman of the Bhayangkara Polda Riau and his ranks, several Heads of Riau Province Offices, several Heads of Dumai City Activities, Deputy Chancellor of Riau University, foreign and domestic researchers, several religious leaders, community leaders, Riau cultural leaders.

Coinciding with the Fun Camp II activity (Bandar Bakau Nature School Campground) on July was 8 to 10 , located in Bandar Bakau Dumai in July 2011. The Alam School students and the Miss Indonesia Finalist representing Riau Province, Revi Lona, carried out an action to plant mangrove trees. This activity is also an Environmental Campaign that coincides with the 2011 Environment Day [38]. With the theme "Knowing \& Loving Coastal Nature," this social activity aims to build awareness of the entire Dumai City community to save the earth's environment, both on land, sea, and air, especially among young students and the general public.

Chevron Pacific Indonesia (PT CPI) and the Nusantara Nature Conservation Foundation, an affiliate of the Nature Conservancy (YKAN TNC), launched the Integrated Coastal Management Development Program in Riau Province and was held in Bandar Bakau, Pengkalan Sesai, Dumai City in the commemoration of World Mangrove Day in 2019. The program is an effort to conserve mangrove forests and their ecosystems by focusing on ecological, social, and economic factors. Employees of PT CPI and YKAN, together with the community, also carried out mangrove planting actions, waste clean-up, and interactive discussions to raise awareness about the importance of mangrove forest conservation. Present on this occasion the Director of Essential Ecosystem Management at the Ministry of Environment and Forestry (BPEE KLHK) Tandya Tjahjana, Riau Province Secretary Ahmad Hijazi, Dumai City Secretary Hamdan Kamal, Head of the Operations Department of SKK Migas Sumbagut Haryanto Syafri, and representatives of the Bengkalis Regency Government [39].

Minister of Tourism and Creative Economy Arif Yahya and Riau Governor Syamsuar and Dumai Mayor Zulkifli AS planted mangrove trees in the Bandar Bakau Dumai tourist area in Dumai City, Riau on August 20nd, 2019 [40]. The Branch Leadership Council (DPC) of the Indonesian Democratic Party (PDI-P) Dumai City carried out an activity to plant 730 mangrove trees in Pangkalan Sesai village, West
Dumai district Sunday (16/2/2020). This activity is to commemorate the 47th Anniversary of the PDI-P and the 73rd Anniversary of PDI-P general chairman $\mathrm{Hj}$ Megawati Soekarno Putri [41].

The women from the Bayangkari group in the Riau area and accompanied by a group of women from the Bayangkari Dumai Bengkalis branch to the location of the mangrove forest, saw the mangrove batik craft made by the Darwis group. The group also carried out mangrove planting activities, and they seemed to enjoy enjoying the sea atmosphere of the Bandar Bakau Dumai mangrove beach and walking on the Sesai beach [42].

On the commemoration of the 75th Independence Day of the Republic of Indonesia and World Mangrove Day on 26 July 2020, the Governor of Riau chose Bandar Bakau Dumai for the peak day of activities and symbolic planting. On this occasion, 2,020 mangrove seedlings have been planted in the species of Avicennia and mangroves in Dumai City. Also, present on occasion were elements of the Riau Regional Leadership Communication Forum (Forkopimda), including Riau Police Chief Inspector General Pol Agung Setya Imam Effendi, Danrem 031/Wirabima Brigadier General TNI Inf Syech Ismed, Danlanud Marsma TNI Ronny Irianto Moningka, Riau DPRD Chairman Indra Gunawan Eet, Deputy Chairperson DPRD Riau Hardianto. In addition, representatives of the Ministry of LHK RI, Secretary-General of Climate Change Control Novia Widyaningtyas, Head of the Indragiri Watershed and Protected Forest Management Center, Rokan Tri Esti Indrawa, Head of Sub-Directorate for Natural Resources Community, Directorate General of Social Forestry and Environmental Partnerships, Umi Rusnawati, Head of Sub-Directorate for Control of Seed Circulation, Directorate General Watershed and Protected Forest Control, and other elements [43].

\subsubsection{Development of environmental adapting facilities}

The tidal flood in Dumai City has caused losses in damaged facilities and infrastructure at the Bandar Bakau Dumai ecotourism site. For minimizing the impact of damage to the facilities and infrastructure, the building is made by adapting to environmental conditions. The form of building adaptation that has been implemented in Bandar Bakau Dumai is in the form of building design in the form of a stilt building, the size of the building is not large, and the placement of the building takes into account the distribution zone of the mangrove ecosystem. The design of the building with a stilt shape aims not to disturb the flow of water and be submerged at high tide and not to seize the mangrove living area. It is in line with what has been implemented in eco-tourism sites in the Wonorejo mangrove conservation area [44]. His research found that the application of adaptive principles that can adapt to the environment, ecosystem, and changing natural conditions, where the function of the building without much damage to the ecosystem. On the other hand, he conveyed those large buildings were not placed in the buffer zone, and the track/courtyard/jetty was built in the space between the mangrove trees to reduce interference and not disturb the function and still follow the function ecosystem order.

\subsubsection{Coastal education}

Coastal education aims to instill a high level of care, love, and responsibility for the coastal and mangrove environment. These characters cannot be obtained instantly; however, they require a relatively long process and time. According to 
literature [45] that the character of caring for the environment requires continuous and continuous habits so that his actions can be expressed in everyday life.

Bandar Bakau has the main character as a place for coastal education through the Bandar Bakau Natural School (SABB). SABB students come from various ages from Kindergarten (TK) and Elementary School (SD) to General High School (SMU) or equivalent, which study and live in Dumai City. SABB's plans are a) making the Dumai River Mangrove forest area one of the sites of the Legend of Putri Tujuh and the history of the founding of Dumai City, b) preserving coastal forests so that they remain stable, protecting beaches and river cliffs, preventing coastal abrasion, protecting areas in the coastal areas. The rear of the waves and strong winds prevent salt intrusion towards the land, and c) make the Dumai River Mangrove Conservation area one of the natural attractions of Dumai City. The expectations of the establishment of SABB are a) forming cadres for mangrove conservation in Dumai city, b) so that students have a caring spirit and understand the preservation of the environment in which they live and work, and c) train students to be independent, skilled and togetherness with one another.

In the learning process, $\mathrm{SABB}$ applies the learning while playing method. SABB combines the National curriculum and the Natural School in learning activities, but the dominant one is the Natural School curriculum. So that in learning activities, students do less theory and more practical activities. The materials presented are a) Special materials, containing: Identification of mangrove species, Cultivation, Rehabilitation techniques, Environmental ethics, Survivers, and Outbound; b) Supporting materials, containing: organization, spirituality, arts, and skills.

SABB teaches students to learn independently; that is why one of the activities of Saving Mud is taught to students. Saving Mud is a mangrove nursery activity in polybags as a place for it. This mud-saving activity has made Bandar Bakau Dumai a "mangrove seed bank." The mangrove seedlings produced are ready to be sold or donated and distributed to parties in need, for example, in reforestation actions, inside and outside Dumai City. SABB students will receive the proceeds from the sale of mangrove seedlings at the time of grade promotion in public schools (Elementry school, Yunior High School, and Senior High school). It is in addition to being additional pocket money; it is also to help the needs of parents for their children who are going to grade or go to school."

\subsubsection{Community counseling}

According to information from the management of Bandar Bakau Dumai, among the problems of the slow development of mangrove eco-tourism in this area, such as the lack of knowledge, awareness, and community participation in developing businesses related to the utilization of mangrove eco-tourism potential in Bandar Bakau Dumai. For this reason, it is deemed necessary to carry out outreach activities to the community. Counseling to the community aims to increase awareness and foster socio-cultural-economic communities based on the sustainability of the coastal and mangrove environment. Socialization activities also aim to increase the role of the community through empowerment, as stated by Ramlan et al. [4]. The concept of the importance of optimizing the use of eco-tourism potential on mangrove forest lands in the context of disaster prevention in Lubuk Kertang village needs to be done through community empowerment and increasing the capacity of the Lubuk Kertang village government apparatus as a manager of eco-tourism activities. It helps formulate policies for managing and utilizing the ecotourism potential of mangrove forest land at the village level.

Sulastri et al. [46] stated that to increase the role of the community in managing mangrove ecosystems for disaster mitigation in Segara Anakan, Cilacap regency. It can be carried out by awareness of the importance of ecosystem conservation to the community in preserving ecosystems and applying alternative policies to manage ecosystems sustainably. It can be more synergistic and accelerate the development of eco-tourism areas.

\subsubsection{Potentially developed disaster mitigation efforts}

According to literature [4], the community has a significant role in maintaining environmental sustainability, so efforts are needed to increase awareness, concern, and love for nature and the environment and discipline towards existing regulations and norms. The potential non-structural mitigation efforts can be developed to anticipate floods and coastal abrasion in Bandar Bakau Dumai, including strengthening laws and regulations, making land-use policies, policies on flood and wave resistant building standards, policies on exploration and community economic activities, as well as elevating the local cultural wisdom of the maritime community. Meanwhile, structural disaster mitigation efforts that can be developed in the future in Bandar Bakau Dumai include beach nourishment, breakwaters, construction of embankments to minimize abrasion, and construction of diversion canals and sluice gates tidal flood control.

\section{CONCLUSIONS}

Natural disasters that often occur in Dumai include coastal abrasion, coastal erosion and tidal flooding can be minimized by utilizing mangrove ecotourism as mitigation. Mangrove ecotourism in the mangroves also has several supporting natures such as birds, mollusks and reptiles. There are 9 types of mangroves found in the mangrove port with the characteristics of preventing abrasion, preventing erosion and also working as a breakwater.

Several disaster mitigations have been carried out to minimize the threat from these natural disasters, including a) construction of revetments, b) Mangrove restoration, c) construction of facilities that adapt to the environment, d) coastal education, and e) outreach to the community. In addition, it is very potential to develop several other forms of mitigation such as beach nourishment, breakwater, or construction of embankments to minimize abrasion, as well as the construction of diversion canals and tidal flood control gates, strengthening regulations, legislation, making land-use policies, policies on flood and wave resistant building standards, policies on exploration and community economic activities, promoting local cultural wisdom of maritime communities.

\section{ACKNOWLEDGMENT}

The results of this study are part of the research budgeted through the University of Riau Leading Research scheme for the 2020 fiscal year. Therefore, the authors thank Riau University for facilitating the financing of this research. The authors also express gratitude to the manager of mangrove 
eco-tourism at Bandar Bakau Dumai, and all parties who have contributed to the successful implementation of this research.

\section{REFERENCES}

[1] Diposatono S. (2003). Natural disaster mitigation in coastal areas in the framework of integrated coastal management in Indonesia. Jurnal ALAMI: Jurnal Air, Lahan, Lingkungan, dan Mitigasi Bencana, 8(2): 1-8.

[2] Data dan Informasi Kota Dumai. (2020). Sumber: https://datin.dumaikota.go.id/, accessed on Oct. 5, 2020.

[3] https://riaulink.com. (2020). Akibat Rob, Sebagian Wilayah Dumai Terendam Banjir. RiauLink.com.

[4] Ramlan, R., Hakim, N., Yusrizal, M., Fajriawati, F. (2018). Optimalisasi potensi ekowisata di lahan hutan bakau dikaitkan dengan upaya pencegahan bencana pada wilayah pesisir desa lubuk kertang. Borneo Law Review Journal, 2(1): 1-15. https://doi.org/10.35334/bolrev.v2i1.718

[5] Senoaji, G., Hidayat, M.F. (2016). The role of mangrove ecosystem in bengkulu coastal city in mitigation of global warming through carbon storage penyimpanan. Jurnal Manusia dan Lingkungan, 23(3): 327-333. https://doi.org/10.22146/jml.18806

[6] Ointu, S.N.A., Tarore, R.C.H., Sembel, A.S. (2015). Tsunami disaster mitigation in molibagu coastal area. Jurnal Spasial: Perencanaan Wilayah dan Kota, 2(3): 90101.

[7] Dinilhuda, A., Akbar, A.A., Jumiati, J. (2018). Peran ekosistem mangrove bagi mitigasi pemanasan global. Jurnal Teknik Sipil, $18(2)$ : $1-8$. http://dx.doi.org/10.26418/jtsft.v18i2.31233

[8] Iqbal, M.N.M., Nugroho, A.M., Haripradianto, T. (2013). Mangrove rehabilitation center kraksaan-probolinggo with ecotourism concept. Jurnal Mahasiswa Jurusan Arsitektur Universitas Brawijaya, 1(1).

[9] Fitrianingsih, Y.R. (2017). Kajian ekowisata untuk konservasi mangrove: Studi kasus di kecamatan langsa barat kota langsa provinsi nangroe aceh darussalam. Journal of Aceh Aquatic Science, 1(1): 83-94. https://doi.org/10.35308/.v1i1.686

[10] Muhammadi, Arlis, S., Chandra. (2018). Mangrove forest conservation and ecotourism development of mangrove villages in medan labuhan and bagan serdang. Jurnal Pembangunan Perkotaan, 8(2): 77-81. http://ejpp.balitbang.pemkomedan.go.id/index.php/JPP/ article/view/42/25.

[11] Alikodra, H.S. (2019). Ecotourism-Based Tourism Development Model on Rupat Island and Basu Island, Provinsi Riau. IPB Press.

[12] Mulyadi, A., Efriyeldi and Marbun, B. (2021). Mangrove ecotourism development strategy in Bandar Bakau Dumai, Riau. Dinamika Lingkungan Indonesia, 8(1): 4856. http://dx.doi.org/10.31258/dli.8.1.p.48-56

[13] Noor, Y.R., Khazali, M., Suryadipura, I.N.N. (1999). Guide to Introduction to Mangroves in Indonesia. PKA/WI-IP, Bogor.

[14] Mulyadi, A. (2017). Mangroves at the Riau University Campus - Revised Edition. Unri Press.

[15] Kota Dumai Dalam Angka. (2019). Badan Statistik Kota Dumai. 314 halaman.

[16] https://wisataterbaru.net/tempat-wisata-di-dumai/. 14 Most Romantic Tourist Attractions in Dumai Riau, accessed on Oct. 24, 2020.

[17] Asbullah, Saam, Z., Thamrin, Isjoni. (2020). Implementation of environmental management in raising environmental awareness of students at Bandar Bakau Nature School in Dumai City, Indonesia. Ecology, Environment and Conservation, 26(2): 837-841.

[18] Sitompul, R.H., Khairijon, Fatonah, S. (2014). Litter production based on zoning in the mangrove area of Bandar Bakau Dumai-Riau, Jurnal Online Mahasiswa, 1(2): 492-499.

[19] Mulyadi, A., Amin, B. (2016). Vegetation structure and mangrove ecosystem threats in the coastal zone of Dumai, Riau, Indonesia. International Journal of Applied Environmental Sciences, 11(3): 785-798.

[20] Susanto, R.B., Yoza, D., Arlita, T. (2016). Potential and carrying capacity of mangrove forest ecotourism area in bandar bakau dumai. Jurnal Online Mahasiswa, 3(2): 111.

[21] Mandari, D.Z., Gunawan, H., Isda, M.N. (2016). Assessment of Biomass and Stored Carbon in Mangrove Ecosystems in Dumai. Bandar Bakau Area. Jurnal Riau Biologia 1(3): 17-23.

[22] Alqarni, W., Sulistyani, A. (2017). Management of the mangrove ecotourism visitor facility in the Bandar Bakau, Dumai city. Jurnal Online Mahasiswa, 4(1): 1-16.

[23] Adhienirma, H.S., Firzal, Y., Faisal, G. (2017). Design of the Bandar Bakau Marine School in Dumai. JOM FTEKNIK, $4(1)$. file://C:/Users/User/AppData/Local/Temp/15089. 29349-1-SM.pdf.

[24] Wanda, W.N., Mulyadi, A., Efriyeldi, E. (2019). Economic valuation of mangrove forest in Dumai City Area, Riau Province. Jurnal Ilmu Lingkungan, 13(1): 109-122. http://dx.doi.org/10.31258/jil.13.1.p.110-122

[25] Darmi, T., Setyawati, R., Yanti, A.H. (2017). Species of gastrophods in mangrove area of estuary of Kuala Baru River, District of Jawai, Sambas Regency. Journal of Biology Sciences Protobiont, 6(1): 29-34. http://dx.doi.org/10.26418/protobiont.v6i1.18154

[26] Nayli, Z., Ali, M., Kamal, S. (2018). Species of bivalves in the mangrove ecosystem area, Kutaraja District, Banda Aceh City. Prosiding Seminar Nasional Biotik.

[27] Nedi, S., Pramudya, B., Riani, E., Manuwoto. (2010). Characteristics of the rupat strait water environment. Jurnal Ilmu Lingkungan, 1(4): 25-35. http://dx.doi.org/10.31258/jil.4.01.p.25-35

[28] Wati, R.A., Rifardi, Mubarak. (2020). Waves and tidal current on high tide (spring tide condition) in Rupat Strait Riau Province. Jurnal Perikanan dan Kelautan, 25(1): 15. http://dx.doi.org/10.31258/jpk.25.1.1-5

[29] https://www.halloriau.com. (2020). Ditanami 2020 Bibit Mangrove, Gubri Sebut Abrasi di Dumai Cukup Tinggi.

[30] Prabowo, H., Buchori, I. (2018). Mitigasi yang Diinisiasi Masyarakat Akibat Abrasi di Kawasan Pesisir Kota Semarang. Teknik PWK Perencanaan Wilayah Kota, 7(1): 44-55.

[31] Ruswandi., Saefuddin, A., Mangkuprawira, S., Riani, E., Kardono, P. (2008). Identification of potential natural disasters and the most appropriate mitigation efforts to be implemented in the Indramayu and Ciamis Coasts. Jurnal Riset Geologi dan Pertambangan, 18(2): 1-19. http://dx.doi.org/10.14203/risetgeotam2008.v18.12

[32] Kurniawan, E. (2020). Coastal Protective Structures to Prevent Abrasion at PPI Salibabu, SKPT Talaud. 
Direktorat Jenderal Pengelolaan Ruang laut. Direktorat Jasa Kelautan. KKP. https://kkp.go.id/djprl/jaskel/artikel/16970

[33] Srimulatsih, U., Sundoro, G.H. (2011). Teknologi batu curah (dump stones) sebagai pengaman tebing sungai. Jurnal Teknik Hidraulik, 2(1): 81-96. https://doi.org/10.32679/jth.v2i1.247

[34] Santoso, D., Yamin, M., Makhrus, M. (2019) Penyuluhan tentang mitigasi bencana tsunami berbasis hutan mangrove di desa ketapang raya kecamatan keruak lombok timur. Jurnal Pengabdian Magister Pendidikan IPA, 2(1):

12-16. https://doi.org/10.29303/jpmpi.v1i2.242

[35] Damayanti, C., Amukti, R., Suyadi. (2020). Potential of mangrove forest vegetation for mitigation of seawater intrusion on small islands. Oseanologi dan Limnologi di Indonesia, $5(2)$ :

75-91. https://doi.org/10.14203/oldi.2020.v5i2.313

[36] Indarsih, R., Masruri, M.S. (2019). Mangrove conservation as an abration strategy risk reduction based on ecosystem in the coastal area of the Rembang Regency. IOP Conference Series: Earth and Environmental Science, 271: 012021. https://doi.org/10.1088/1755-1315/271/1/012021

[37] Oni, O., Kusmana, C., Basuni, S. (2019). Success story mangrove ecosystem rehabilitation at Karangsong Beach, Indramayu Regency. Jornal of Natural Resources and Environmental Management, 9(3): 787-796. http://dx.doi.org/10.29244/jps1.9.3.477-487

[38] Miss Riau 2010, Revi Lona Plants Mangrove. http://mangrovedumai.blogspot.com.
[39] Hari Mangrove se- Dunia, KLHK Tanam Bibit Mangrove di Dumai. https://riaukepri.com, accessed on Dec. 24, 2020.

[40] Menteri Pariwisata ke Bandar Bakau Dumai. https://otomotif.antaranews.com, accessed on Dec. 24, 2020.

[41] Penanaman Pohon PDI Perjuangan Kota Dumai, Uber Firdaus: Sungai dan Bakau Simbol Peradaban, https://www.riaupembaruan.com, accessed on Dec. 24, 2020.

[42] Kunjungan Kerja Bayangkari Daerah Riau ke Hutan Mangrove Bandar Bakau Dumai, https://www.wasiatriau.com, accessed on Oct. 24, 2020.

[43] Peringati Hari Mangrove Se Dunia: GubernurForkopimda Riau Tanam Pohon Mangrove di Dumai, https://www.oketimes.com, accessed on Dec. 24, 2020.

[44] Rachmadanti, R., Antaryama, I.G.N. (2013). Implementation of adaptation principe on ecotourism building design in wonorejo mangrove conservation area. Jurnal Sains dan Seni Pomits, 2(2): G54-G57. https://doi.org/10.12962/j23373520.v2i2.3438

[45] Jayawardana, H.B.A. (2016). Pendidikan karakter peduli lingkungan sejak dini sebagai upaya mitigasi bencana ekologis. Prosiding Symbion (Symposium on Biology Education), Prodi Pendidikan Biologi, FKIP, Universitas Ahmad Dahlan, pp. 49-64.

[46] Sulastri, E., Haryadi, F.T., Inayah, E. (2019). Ecological awareness level of community of Kampung Laut, Cilacap Regency, Jawa Tengah. Jurnal Kawistara, 9(1): 78-90. https://doi.org/10.22146/kawistara.31484 